KeMAS 16 (2) (2020) 169-174
Jurnal Kesehatan Masyarakat

\title{
Parenting and Family Conflict with Dating Violence among youth in Yogyakarta
}

\author{
Suci Musvita Ayu ${ }^{凶}$, Lisa Triyani \\ Public Health Science Program, Public Health Faculty, Ahmad Dahlan University, Yogyakarta, Indonesia
}

\begin{tabular}{l} 
Article Info \\
\hline Article History: \\
Submitted November 2019 \\
Accepted January 2020 \\
Published November 2020 \\
\hline Keywords: \\
Violence in Dating, \\
Conflict in Family, Parenting \\
\hline DOI \\
https://doi.org/10.15294/ \\
kemas.v16i2.22072
\end{tabular}

\begin{abstract}
Violence in dating is classified as a form of behavior disorder of teenagers whose cases are common in the surrounding environment but are sometimes not realized either by the victim or even by the perpetrators themselves. Violence in dating can have a negative impact on the victim. Based on the facts in the field conducted in 2019, it is known that majority parenting is permissive and tends not to have problems or conflicts in the family. This research is intended to look at the relationship between parenting and conflict in the family with acts of violence in dating. This research used a cross sectional design with chi square analysis. The research sample of 147 people was obtained by proportional random sampling technique. The instrument used was a questionnaire to measure parenting and family conflict. The results showed that there is a relation between parenting $(\mathrm{p}=0.014 ; \mathrm{RP}=0.691)$ with the incidence of violence in courtship. And there is no relation between conflict in the family ( $p=0.102$; $R P=1.789)$ with the incidence of violence in dating. Parenting can contribute to the mindset of children, so that what they see can cause children to do things that are not much different as in violence in dating. Attention, guidance, motivation and taking time with children is a way of approaching children that can make the relationship between parent and child harmoniously established.
\end{abstract}

\section{Introduction}

Teenage is a transition from childhood to adulthood in all aspects of development (Santrock, 2003). Dating relationships are considered to be a means of establishing friendship, emotional support, affection, pleasure, and sexual exploration. Dating can make people feel no longer lonely, giving awareness that there is someone who always gives attention and becomes an encouragement in doing all activities (Nurhasanah, 2017).

In Indonesia, acts of violence both individually and in groups are daily news that are almost always presented by the mass media, both print and electronic (Aisyah, 2010). Violence in dating is an act of violence against a partner who is not bound by marriage which includes physical, psychological and economic violence. Most of the victims are women, this is caused by several factors ranging from fear, guilt, nausea and feeling lack of social and individual support (Komnas Perempuan, 2016). Women are more vulnerable to psychological abuse than men (Vagi dkk, 2018). Spouse violence is a crime against women committed by known people and occurs in places that are considered safe such as home or work (Lawson, 2012).

The Indonesian Family Planning Association (PKBI) Yogyakarta released data explaining that of 125 teenagers respondents, consisting of 75 female and 50 male, 84 percent had experienced violence. A survey conducted by PKBI Yogyakarta in February 2017 proved that most teenagers in Yogyakarta had experienced violence. The forms of violence experienced were $64 \%$ psychological, $43.2 \%$ sexual and $33.6 \%$ physical violence. The survey also found that the average teenagers experienced two 
to three types of violence at once. As many as $12 \%$ of respondents experienced psychological, sexual and physical violence. While around $34.4 \%$ of respondents experienced two types of violence from their partners, namely sexual and physical violence as much as $4 \%$, physical and psychological violence as much as $11.2 \%$, and sexual and psychological violence as much as 19.3\% (PKBI, 2017). Russell et al. (2014) reported that as many as $78.5 \%$ of students had had a dating partner in the last three months and during that period, they reported a high level of violence on partners in which more than $10 \%$ of male teenagers reported forcing partners to have sex, and $39 \%$ female teenagers reported experiencing physical violence by their partners (Russell, Jewkes, \& Mathews, 2014). Recent research conducted in Indonesia stated that $59.2 \%$ of teenagers have committed violence against their partners (Ayu, Sofiana, \& Jayanti, 2019).

The results of observations and interviews with one of the teachers at SMK Piri 1 Yogyakarta stated that in previous years that the students were often involved in brawl with other schools. Although SMK Piri I students' have long school hours that lasting from morning to evening and continued with extracurricular activities. The problem that often occurs in SMK Piri 1 Yogyakarta is at breaking hours many students are outside the school, students often skip school and smoke in the school area. In December 2017 there had been violence between students of class XI and class XII because the class XI student took the class XII student's girlfriend, so the problem was brought on a trial and at the end of 2017 there was a case that one of the SMK Piri I student was in a boarding room with dating partner and they were secured by local residents and residents reported the students to the police and the school. Based on the background that has been described previously, researcher was interested to examine the "Relationship between Parenting And Family Conflict With The Occurrence Of Violence Incident in Dating among Teenagers at SMK Piri 1 Yogyakarta". Method

This type of research is a quantitative observational cross-sectional design. This research was conducted at SMK Piri
1 Yogyakarta. Sampling was done with proportional random sampling and obtained 147 students. Sampling techniques that pay attention to consideration of elements or categories in the study population (Sugiyono, 2003). The population of this research is all students of class XI SMK Piri 1 Yogyakarta with a total of 189 , consisting of 10 classes with 5 majors namely Electric Power Installation Techniques (TITL) of 27 students, Audio Visual Engineering (TAV) of 5 students, Machining Engineering (TP) as many as 26 students, Light Vehicle Engineering (TKR) as many as 44 students and Business and Motorcycle Engineering (TSM) as many as 35 students. The inclusion criteria of this study was all students of class XI aged 16-17 years, teenagers who had had dating partner and were willing to be respondents. The exclusion criteria were teenagers who refused to become respondents and did not complete the questionnaire.

\section{Result and Discussion}

Based on Table 1, most respondents were male gender namely $93.9 \%$. Respondents were dominated by teenagers aged 16 years $(53.7 \%)$. The majority of respondents' parent's education was senior high school (61.2\%).

Based on Table 2 of the univariate analysis of conflicts in the family are categorized into two namely conflict and not conflict. Respondents who experienced conflict in the family numbered 125 students (85\%) while respondents who did not experience conflict in the family were smaller, numbered 22 students (15\%). Parenting was categorized into three, namely Democratic, Permissive and Authoritarian. The highest parenting group was permissive, numbered 114 students (77.6\%), while democratic and authoritarian parenting is very low with a democratic number of 19 students (12.9\%) and an authoritarian 14 students (9.5\%). Violence in dating was categorized into two, namely doing and not doing. The results showed that 87 respondents (59.2\%) experienced violence in dating and those who never were 60 respondents (40.8\%). The forms of violence experienced by respondents were physical and psychological one (10.9\%) and economic violence (14.3\%).

Based on Table 3 the bivariate analysis of parenting and dating violence showed that 
Table 1. Distribution of respondent characteristics based on gender, age and parent education.

\begin{tabular}{llll}
\hline Respondents Characteristics & $\Sigma$ & $\%$ \\
\hline Gender & Male & 138 & 93.9 \\
& Female & 9 & 6.1 \\
Age (years) & 16 & 79 & 53.7 \\
\multirow{3}{*}{ Parent Education } & 17 & 68 & 46.3 \\
& Graduate & 19 & 12.9 \\
& Elementary & 8 & 5.4 \\
& Junior High & 18 & 12.2 \\
& Senior High & 90 & 61.2 \\
Total & Unknown & 12 & 8.2 \\
\hline Sourn & & 147 & 100 \\
\hline
\end{tabular}

Source: Primary Data, 2018

Table 2. Univariate Analysis Based on Conflicts in the Family, Parenting and the Occurrence of Violence in Dating

\begin{tabular}{llll}
\hline 1 & Conflict in the Family & \\
\hline & Conflict & 125 & 85.0 \\
& Not Conflict & 22 & 15.0 \\
\hline 2 & Parenting & & \\
\hline & Democratic & 19 & 12.9 \\
& Permissive & 114 & 77.6 \\
& Authoritarian & 14 & 9.5 \\
\hline 3 & Violence in Dating & & \\
\hline & Doing Violence in Dating & 87 & 59.2 \\
& Physical Violence & 16 & 10,9 \\
& Economical Violence & 21 & 14,3 \\
& Psychological Violence & 16 & 10,9 \\
& Not doing Violence & 60 & 40.8 \\
& Total & 147 & 100 \\
\hline
\end{tabular}

Source: Primary Data, 2018

there is a relation between parenting with dating violence. This is indicated by the value of $\mathrm{p}$ value 0.014 ( $\mathrm{p}<0.05$ ). This factor is supported from research which stated that the factors causing violence in dating committed by teenagers consist of internal and external factors. Internal factor is the factor obtained from the experience of parenting on the past, the perpetrator had been a victim of violence or accustomed to acts of violence in the childhood. While external factor is obtained from environmental factor. The causes of violence in dating committed by teenagers include internal and external factors. In internal factor where this factor is derived from parenting experience, the perpetrator has been a victim of violence or accustomed to acts of violence in his childhood. While external factor obtained from the environment is peers who have a very big impact on the lives of teenagers (Mahmudah, Yaunin, \& Lestari, 2016).

Parenting that can influence adolescent behavior to commit violence in dating one of which is authoritarian model. Authoritarian 
Table 3. Bivariate Analysis Based on Conflicts in the Family, Parenting and the Occurrence of Violence in Dating

\begin{tabular}{|c|c|c|c|c|c|c|c|c|}
\hline \multirow{3}{*}{ No } & \multirow{3}{*}{ Variable } & \multicolumn{4}{|c|}{ Violence in Dating } & \multirow{3}{*}{$\mathrm{RP}$} & \multirow{3}{*}{ CI 95\% } & \multirow{3}{*}{ p-value } \\
\hline & & \multicolumn{2}{|c|}{ Doing } & \multicolumn{2}{|c|}{ Not Doing } & & & \\
\hline & & $\mathrm{n}$ & $\%$ & $\mathrm{n}$ & $\%$ & & & \\
\hline \multirow[t]{3}{*}{1} & Parenting & & & & & \multirow{3}{*}{0.691} & \multirow{3}{*}{$0.518-0.921$} & \multirow{3}{*}{0.014} \\
\hline & Not Democratic & 33 & 47.8 & 36 & 52.2 & & & \\
\hline & Democratic & 54 & 46.2 & 24 & 31.8 & & & \\
\hline \multirow[t]{3}{*}{2} & Conflict in the Family & & & & & & & \\
\hline & Conflict & 61 & 57.0 & 64 & 68.0 & \multirow{2}{*}{1.789} & \multirow{2}{*}{$0.884-3.624$} & \multirow{2}{*}{0.102} \\
\hline & Not Conflict & 6 & 10.0 & 16 & 12.0 & & & \\
\hline
\end{tabular}

parents tend to use violence in giving punishments that result in children in daily life will behave more aggressively and imitate what parents do when they are outside the home (Sagala, 2008). Authoritarian parenting has tendency to affect the symptoms of aggressive behavior in teenagers (Dewi \& Susilawati, 2016).

Parenting that is free and not too restrictive as long as it is within reasonable limits can also affect teenagers in committing violence in dating (Lestari, Nurjanah, \& Martunis, 2018). Limited knowledge and education of parents will have difficulty in applying good parenting. Discrepancies obtained with the hope of causing children to be closed with parents. Emotional problems that are neglected by parents can lead to problems for teenagers (Mesra, Salmah, \& Fauziah, 2014).

Educated mother is an indicator of one's success in educating children. The higher the education, a parent will mature how to think, how to educate and provide information to children. Children who are given the right information will have good knowledge (Mesra et al., 2014). Good parenting style will affect teenagers dating behavior (Dari \& Ratnawati, 2015).

Based on the analysis result of conflict in the family and violence in dating showed that there is no relation between conflict in the family with violence in dating in SMK Piri 1 Yogyakarta. This is indicated by the $\mathrm{p}$ value of $0.102(p>0.05)$. Based on data collection in the field, most respondents do not have conflicts or problems with their families. The violence act can be affected by other factors such as peers influence, parenting and the role of the teacher. Like previous research which stated that conformity with peers contributes to the emergence of violence in dating behavior in teenagers. Teenagers who gather with friends who are often victims of violence in dating, tend to receive such treatment from their partners because they do not want to lose the partner (Savitri et al., 2015). In teenage, teenagers are more likely to be closer with friends and more trust with their dating partners or friends.

This result is not in line with research which stated that there are factors that affect dating violence, namely parenting, conflict in family and peer relations (Savitri et al., 2015). The result of the study mentioned that the family is the first social environment that gives a very big effect on the growth and development of teenagers (Marshia Zefanya, 2016). Ideally the development of teenagers will be optimal if they are with a harmonious family. Lack of parental attention can cause the victim to seek outside attention in hopes of getting it from a dating partner or lover. Parents who rarely spend time with children, causing victims to be more comfortable hanging out outside the house hoping that they will get attention (Mesra et al., 2014).

Conflict in the family can be influenced by communication that occurs in the family. The better the quality of family communication, the better the communication process of an individual outside the family environment, this 
will affect the way he behaves towards others. The more quality of family communication that takes place, the lower the violent behavior in dating (Astari \& Santosa, 2017). Children involved in family conflicts are positively related to child developing issues (Jouriles, Rosenfield, Mcdonald, \& Mueller, 2015).. Children who witness first hand the conflicts that occur to their parents will have an unfavorable experience, which can be carried by children into adulthood so as to have many types of violence (Telleria, 2019).

Parents who show violence, hostility, inconsistency, and lack of warmth are very dangerous to warmth and good protection when the child lives under threat. How much and what is shown by parents and families will form children in the future (Eltanamly, Leijten, Jak, \& Overbeek, 2019). It can even affect the way they interact with fellow individuals (Alberto et al., 2018). Cases that cause children to abuse parents are not only caused by parenting or conflicts in the family, but a bad environment can also affect them in carrying out acts of violence. Intervention that can be suggested to avoid child violence against parents is by educating with strict discipline and parents can also ask for help from those who can be trusted if needed (Ibabe, 2019).

Ways to prevent violence in dating are, starting with the belief that our bodies are valuable, defining concretely the meaning of dating and how relationships will be fostered, daring to say "no", learning to be yourself, seeking support, creating an anti-violence community, seeking parental assistance and also experts, fortify themselves with sufficient faith and religious knowledge and not dating ( $\mathrm{Ayu}$, Hayati, \& Hakimi, 2013). Good communication pattern in the family is also needed, because poor or non-positive communication patterns can increase emotional abuse in teenagers (Pemayun \& Widiasavitri, 2015). Emotional abuse can affect the incidence of violence in dating, because violence in dating also takes the form of verbal or symbolic aggression, namely in the form of harsh words, words that are not worth listening to, vilifying, demanding, threatening and limiting relationships with others (Khaninah \& Widjanarko, 2016).

\section{Conclussion}

There is a relation between parenting with the incidence of violence in dating at SMK Piri I Yogyakarta with a p value of 0.014. There is no relation between conflict in the family with violence in dating at SMK Piri I Yogyakarta with a $\mathrm{p}$ value of 0.102 . What can be highlighted from this research is attention, guidance, motivation and taking time with children are ways of approaching children that can make the relationship between parents and children harmoniously established. And it is important that parents can also ask for help from those who can be trusted if needed when experiencing difficulties in guiding children.

\section{Reference}

Alberto, A., Cuervo, V., Quintana, J. T., Alonso, E., Martínez, C., \& Rafael, T. (2018). Challenging Behavior, Parental Conflict and Community Violence in Students with Aggressive Behavior. International Journal of Psychological Research, 11(1), 50-57. https:// doi.org/10.21500/20112084.1777

Astari, C., \& Santosa, H. P. (2017). Hubungan antara Kualitas Komunikasi Keluarga dan Persepsi tentang Abusive Relationship dengan Perilaku Kekerasan dalam PacaranKelompok Usia Dewasa Muda. E-Jounal Undip, 7(2), $1-12$.

Ayu, S. M., Hayati, E. N., \& Hakimi, M. (2013). Kekerasan dalam pacaran dan kecemasan remaja putri di kabupaten purworejo. Journal KESMAS, 6(1), 61-74. https://doi. org/10.12928/kesmas.v6i1.1067

Ayu, S. M., Sofiana, L., \& Jayanti, F. U. (2019). The correlation of teacher's role, peers, and mass media with the incidence of dating violence in adolescents at SMK Piri 1 Yogyakarta. International Journal OfCommunity Medicine And Public Health, 6(6), 2325. https://doi. org/10.18203/2394-6040.ijcmph20192292

Dari, T. S. U., \& Ratnawati, D. (2015). Hubungan Pola Asuh Orang Tua Dengan Perilaku Berpacaran Pada Remaja Di Sman 6 Depok. Jurnal Keperawatan Widya Gantari, 2(2), 125-144.

Dewi, N. P. A. R., \& Susilawati, L. K. P. A. (2016). Hubungan Antara Kecenderungan Pola Asuh Otoriter ( Authoritarian Parenting Style ) dengan Gejala Perilaku Agresif Pada Remaja Ni Putu Ayu Resitha Dewi dan Luh Kadek Pande Ary Susilawati. Jurnal Psikologi Udayana, 3(1), 108-116.

Eltanamly, H., Leijten, P., Jak, S., \& Overbeek, G. (2019). Parenting in Times of War: A 
Meta-Analysis and Qualitative Synthesis of War Exposure, Parenting, and Child Adjustment. Journal SAGE Pub. https://doi. org/10.1177/1524838019833001

Ibabe, I. (2019). Adolescent-to-Parent Violence and Family Environment: The Perceptions of Same Reality? International Journal of Environmental Research and Public Health, 16(2215), 1-14.

Jouriles, E. N., Rosenfield, D., Mcdonald, R., \& Mueller, V. (2015). Child Involvement in Parental Conflict and Child Adjustment Problems:A Longitudinal Study of Violent Families. J AbornM Child Psychol, 42(5), 693-704. https://doi.org/10.1007/s10802013-9821-1.Child

Khaninah, A. N., \& Widjanarko, M. (2016). PERILAKU AGRESIF YANG DIALAMI KORBAN KEKERASAN DALAM PACARAN. Jurnal Psikologi Undip, 15(2), 151-160.

Komnas Perempuan. (2016). Kasus Kekerasan Dalam Pacaran Selama 2016. Jakarta: Komnas Perempuan. Retrieved from www. databoks.katadata.co.id

Lawson, J. (2012). Sociological Theories of Intimate Partner Violence. J Hum Behav Soc Environ., 22(5), 572-90.

Lestari, W., Nurjanah, \& Martunis. (2018). Dampak Pola Asuh Orang Tuan Terhadap Perilaku Berpacaran (Studi Kasus Di SMP Negeri 3 Banda Aceh). Jurnal Ilmiah Mahasiswa Bimbingan Dan Konseling, 3(2), 42-49.

Mahmudah, Yaunin, \& Lestari. (2016). Faktor-faktor yang Berhubungan Dengan Perilaku Seksual Remaja Di Kota Padang. Jurnal Kesehatan Andalas, 5(2), 1-11.

Marshia Zefanya. (2016). Faktor Yang Berhubungan Dengan Praktik Seks Pranikah Di Kalangan Anak Jalanan Kota Semarang Tahun 2016. Jurnal Kesehatan Masyarakat, 4(3), 10291035.

Mesra, E., Salmah, \& Fauziah. (2014). Kekerasan Dalam Pacran Pada Remaja Putri Di Tangerang. Jurnal Ilmu Teknologi Kesehatan, 2(1), $1-8$.
Nurhasanah, L. A. (2017). Interpersonal Communication Strategy For Maintaining Post-Violence Relationship. E-Jounal Undip, 5(3), 1-11.

Pemayun, C. I. I., \& Widiasavitri, P. N. (2015). Perbedaan Emotional Abuse pada Remaja Akhir yang Berpacaran Berdasarkan Pola Komunikasi dalam Keluarga. Jurnal Psikologi Udayana, 2(2), 300-310.

PKBI. (2017). Survei Kekerasan Pada Remaja.

Russell, M., Cupp, P. K., Jewkes, R. K., Gevers, A., Mathews, C., LeFleur-Bellerose, C., \& Small, J. (2014). Intimate Partner Violence Among Adolescents in Cape Town, South Africa. Prevention Science, 15(3), 283-295. https:// doi.org/10.1007/s11121-013-0405-7

Russell, M., Jewkes, R. K., \& Mathews, C. (2014). Intimate Partner Violence among Adolescents in Cape Town, South Africa. Prev Sci, 15(3), 283-295. https://doi.org/10.1007/s11121013-0405-7.Intimate

Sagala, R. (2008). Kekerasan Dalam Pacran Pada Mahasiswa Ditinjau Dari Pola Asuh Otoriter Orang Tua. Katolik Soegijapranata.

Santrock, J. W. (2003). Perkembangan Remaja (6th ed.). Jakarta: Erlangga.

Savitri, A. D., Psi, S., Si, M., Linayaningsih, F., Psi, S., \& Psi, M. (2015). Kekerasan Dalam Pacaran Pada Siswa Sma Ditinjau Dari Konformitas Teman Sebaya Dan Efektivitas Komunikasi Dalam Keluarga. J. Dinamika Sosbud, 17(2), $41-47$.

Sugiyono. (2003). Metode Penelitian Kombinasi (Mixed Method). Bandung: Alfabeta.

Telleria, A. E. A. (2019). Descriptive study of the type of abuse suffered by minors evaluated in the Integral Forensic Evaluation. Spanish Journal of Legal Medicine, 45(1), 4-11.

Vagi, K. J., Olsen, E. O. M., Basile, K. C., \& Alana, M. (2018). Teen Dating Violence (Physical and Sexual) Among US High School Students: Finding From the 2013 National Youth Risk Behavior Survey, 169(5), 474-482. https:// doi.org/10.1001/jamapediatrics.2014.3577. Teen 